Journal of Maternal and Child Health (2018), 3(3): 176-183

https://doi.org/10.26911/thejmch.2018.03.03.02

\title{
Multilevel Analysis on the Determinants of Exclusive Breastfeeding at Gunung Anyar Community Health Center, Surabaya, Indonesia
}

\author{
Zummatul Atika'), Harsono Salimo²), Yulia Lanti Retno Dewi3) \\ ${ }^{1)}$ Masters program in Public Health, Universitas Sebelas Maret \\ 2)Department of Pediatrics, Dr. Moewardi Hospital, Surakarta \\ 3)Department of Nutrition, Faculty of Medicine, Universitas Sebelas Maret
}

\begin{abstract}
Background: Exclusive breastfeeding is provision of breast milk for infants from o to 6 months of age with no additional food or drink intake. Provision of medicine, vitamin, and mineral is allowable during the period of exclusive breastfeeding. There is a lack of studies examining factors associated with exclusive breastfeeding in Surabaya using multilevel analysis. This study aimed to examine factors associated with exclusive breastfeeding in Surabaya using multilevel analysis.

Subjects and Method: This was an analytic observational study with a cross sectional design. The study was carried out at Gunung Anyar community health center (puskesmas), Surabaya, East Java, Indonesia. A total of 25 puskesmas was selected by stratified random sampling, covering both accredited and non-accredited puskesmas. A total of 8 lactating mothers from each puskesmas were selected by simple random sampling. The dependent variable was exclusive breastfeeding. The independent variables were subjective norm, leisure time for breastfeeding, attitude, husband support, family support, and health personnel support. The data were collected by questionnaire and analyzed by a multilevel logistic regression.

Results: Exclusive breastfeeding was positively affected by positive subjective norm $(b=4.31 ; 95 \%$ $\mathrm{CI}=1.63$ to $6.99 ; \mathrm{p}=0.002)$, leisure time for breastfeeding $(\mathrm{b}=3.97 ; 95 \% \mathrm{CI}=1.12$ to $6.81 ; \mathrm{p}=0.006)$, positive attitude $(\mathrm{b}=3.01 ; 95 \% \mathrm{CI}=0.57$ to $5.45 ; \mathrm{p}=0.016)$, strong husband support $(\mathrm{b}=2.39 ; 95 \%$ $\mathrm{CI}=0.29$ to $4.51 ; \mathrm{p}=0.026)$, strong family support $(\mathrm{b}=2.71 ; 95 \% \mathrm{CI}=0.46$ to $4.97 ; \mathrm{p}=0.018)$, and strong health personnel support $(b=4.13 ; 95 \% \mathrm{CI}=1.28$ to $6.99 ; \mathrm{p}=0.005)$. Posyandu showed strong contextual effect on exclusive breastfeeding with intra-class correlation (ICC) $=69.47 \%$.

Conclusion: Exclusive breastfeeding is positively affected by positive subjective norm, leisure time for breastfeeding, positive attitude, strong husband support, strong family support, and strong health personnel support. Contextual effect at posyandu level should be taken into account when estimating factors affecting exclusive breastfeeding.
\end{abstract}

Keywords: exclusive breastfeeding, subjective norm, attitude, husband support, health personnel support

\section{Correspondence:}

Zummatul Atika. Masters Program in Public Health, Universitas Sebelas Maret, Jl. Ir. Sutami 36 A, Surakarta, Indonesia. Email: atikaprayogi6@gmail.com.Mobile:+6289656280307.

\section{BACKGROUND}

Breast milk is the most nutrient intake rich in various nutritional values for children's growth. Breast milk is the best food for babies to be able to meet all the needs of the baby's growth and development process until the age of 6 months. Exclusive breastfeeding from birth can overcome the growth disorders of children due to malnutrition (Astuti, 2013).

Based on a study conducted by Kaushal et al. (2017) in the Himalayas, stated that the target of exclusive breastfeeding achievement of $80 \%$, but found only $56.5 \%$ of mothers who exclusively breastfeed, this occurs because of the 
influence of maternal age, education level, and paternal employment. Exclusive breastfeeding coverage worldwide is only about 36\% (WHO, 2011).

Based on data sources from the monitoring of nutritional status 2016, Directorate General of Public Health, Ministry of Health, 2017, the coverage of infants in Indonesia who get exclusive breastfeeding aged $0-5$ months is $54 \%$, while those aged o-6 months is $29.5 \%$. And newborns who received early initiation of breastfeeding (EIBF) in the first hour was $42.7 \%$, while those who received EIBF were approximately equal to the first 1 hour of birth 9.2\%. The coverage of infants in East Java who received exclusively breastfed aged $0-5$ months was $48.1 \%$, while those aged o-6 months were $31.3 \%$. Newborn infants who received an EIBF in the first hour were 50.7\%, while those who received EIBF were approximately equal to the first 1 hour of birth at 12\% (Budijanto et al., 2016).

Exclusive breastfeeding coverage in Surabaya in 2016 was $64.99 \%$. It was increased $0.66 \%$ in 2017 . It showed the increasing of mother awareness about the importance of exclusive breastfeeding for infants (Surabaya City Health Office, 2016).

In 2017, WHO stated that the best food for infants is breast milk alone from the first day of life until the baby aged 6 months. The provision which states that previously breastfeeding for 4 months is no longer valid (Irianto, 2014).

Based on the background, the author is interested to examine the determinants of the successful breastfeeding exclusive at Gunung Anyar Community Health Center, Surabaya, East Java.

\section{SUBJECTS AND METHOD}

\section{Study Design}

This was an analytic observational study with cross sectional design (Murti, 2013).
The study was conducted at Gunung Anyar Community Health Center, Surabaya, from March to April 2018.

\section{Population and Sample}

In this study, the source population was all mothers who have infants aged 6-12 months in March-April 2018 in Gunung Anyar Community Health Center, Surabaya. As many as 25 posyandus were selected for this study. A sample of 200 mothers from each posyandu was selected by simple random sampling.

\section{Study Variables}

The dependent variable was exclusive breastfeeding. The independent variables were subjective norm, leisure time to breasfeeding, attitude, husband support, family support, and health personnel support.

\section{Operational Definition of Variables}

Exclusive breastfeeding was defined as a balanced nutritional diet given by mothers in newborns to 6 months of age without any food or other beverages except drugs/ medicine and vitamins (Irianto, 2014). The measurement scale was categorical.

The subjective norm was defined as the maternal perception of exclusive breastfeeding behavior that is influenced by the value of social norms in her environment (Sulaeman, 2016). The measurement scale was continuous.

Breast-feeding time was defined as a free or loose time for breastfeeding opportunities in infants until the baby is satisfied with the breastfeeding or the time available to pump breastmilk in the lactation corner (Didik Budijanto et al., 2016). The measurement scale was continuous.

Attitude was defined as an evaluative statement of the object either in the form of an individual or event, whose response is still closed to the stimulus or object. The measurement scale was continuous. 
Journal of Maternal and Child Health (2018), 3(3): 176-183

https://doi.org/10.26911/thejmch.2018.03.03.02

Husband support was defined as the perception of a breastfeeding mother about the motivation or encouragement of the husband about the exclusive breastfeeding, (Abdullah, 2012). The measurement scale was continuous.

Family support was defined as the perception of a breastfeeding mother about the motivation or encouragement of father, mother, grandparents, in-laws, and siblings about the exclusive breastfeeding (Abdullah, 2012). The measurement scale was continuous.

Health personnel support was defined as maternal perception about motivation or encouragement of health workers (midwives, family doctors, cadres) in exclusive breastfeeding (Ramandey, 2017).

Strata of posyandu was defined as posyandu activity conducted by infant and cadre mother in posyandu and posyandu strata score in accordance with criteria from city health office, level of posyandu development which is divided into 4 levels (Indonesian Ministry of Health, 2008). The measurement scale was continuous.

\section{Study Instrument}

The data of this study was collected by questionnaire. The validity test included content and face validity. Reliability test in this study was conducted on 20 mothers who have infants aged 6-12 months in Gunung Anyar community health center, Surabaya, East Java. The reliability test was performed by measuring the variables using the SPSS statistical program which can calculate the total-item correlation $(\geq 0.20)$ and Cronbach alpha $(\geq 0.70)$.

\section{Data Analysis}

The data analysis was conducted using multilevel analysis with Stata 13 program to know the influence of determinant influence. Multilevel analysis steps in this study included the multilevel model providing a powerful technical framework that can be used to analyze the correlation properties of variables and relevant when the predictor variables are measured simultaneously. Furthermore, multilevel analysis was conducted to generate access as the effect of all levels that are tested by multilevel logistic regression model analysis using STATA 13 program.

\section{Research Ethics}

This research was carried out after obtaining some research requirements from the Research Ethics Commission of Public Health Faculty of Sebelas Maret University in the form of a letter of ethical clearance in the form of a research permit in the area of Gunung Anyar Community Health Center, Surabaya which was issued by the ethics commission of Dr. Moewardi hospital, Surakarta, Central Java.

\section{RESULTS \\ 1. Sample Characteristics}

The characteristics of subjects in this study were 200 subjects. The frequency distribution of the characteristics of the study subjects is described in Table 1. It indicates that infants who did not receive exclusive breastfeeding were 105 (52.5\%). As many as 103 mothers $(51.5 \%)$ had strong subjective norms. As many as 107 mothers (53.5\%) had positive attitude. As many as 114 mothers (57\%) had husband support. 113 mothers $(56.5 \%)$ received strong family support. 107 mothers (53.5\%) received weak health personnel support.

\section{Multilevel analysis}

The relationship of variables studied was then analyzed using multilevel analysis model. Variables at level one that directly affect the individual included maternal nutritional status, parity, occupation, family income, support of health workers, and subjective norms, while the variable at level two was posyandu. 
The multilevel analysis model in this study used multilevel logistic regression analysis because it is a very powerful statistical instrument to analyze the relationship between exposure and disease simultaneously controlling a number of potential confounding factors with regression coefficient variable size (b). The magnitude of the effect on the two levels is indicated by a parameter called Intra Class Corelation (ICC).

The multilevel model provides a powerful technical framework that can be used to analyze the correlation properties of variables and relevant when predictor variables are measured simultaneously. The first level multilevel analysis is on indi-

Table 1. Sample Characteristics

\begin{tabular}{|c|c|c|}
\hline Characteristics & Frequency (n) & Percent (\%) \\
\hline \multicolumn{3}{|l|}{ Exclusive Breastfeeding Status } \\
\hline - No exclusive breastfeeding (code o) & 105 & 52.5 \\
\hline - Exclusive breastfeeding (code 1) & 95 & 47.5 \\
\hline \multicolumn{3}{|l|}{ Subjective Norms } \\
\hline - Weak < 34 (code o) & 97 & 48.5 \\
\hline - Strong $\geq 34(\operatorname{code} 1)$ & 103 & 51.5 \\
\hline \multicolumn{3}{|l|}{ Breastfeeding Time } \\
\hline - No breastfeeding time $<3$ (code 0$)$ & 99 & 49.5 \\
\hline - Breastfeeding time $\geq 3(\operatorname{code} 1)$ & 101 & 50.5 \\
\hline \multicolumn{3}{|l|}{ Attitude } \\
\hline - Negative $<24$ (code o) & 93 & 46.5 \\
\hline - Positive $\geq 24(\operatorname{code} 1)$ & 107 & 53.5 \\
\hline \multicolumn{3}{|l|}{ Husbands' Support } \\
\hline - Not supportive < 4 (code o) & 86 & 43.0 \\
\hline - Supportive $\geq 4(\operatorname{code} 1)$ & 114 & 57.0 \\
\hline \multicolumn{3}{|l|}{ Family Support } \\
\hline - Not supportive $<9$ (code 0$)$ & 87 & 43.5 \\
\hline - Supportive $\geq 9(\operatorname{code} 1)$ & 113 & 56.5 \\
\hline \multicolumn{3}{|l|}{ Health Personnel Support } \\
\hline - Not supportive < 9 (code o) & 107 & 53.5 \\
\hline -Supportive $\geq 9(\operatorname{code} 1)$ & 93 & 46.5 \\
\hline \multicolumn{3}{|l|}{ Posyandu Strata } \\
\hline - Madya (code 1$)$ & 120 & 60.0 \\
\hline - Purnama (code 2) & 80 & 40.0 \\
\hline
\end{tabular}

vidual characteristics, while the second level is at posyandu. Furthermore, multilevel analysis to generate access as the effect of all levels was conducted by multilevel logistic regression analysis using the STATA 13 program.

The results of multilevel analysis in this study were $69.47 \%$ of maternal variation in exclusive breastfeeding, determined by the posyandu visited by the mother for about $69 \%$ on average all the variables influence in exclusive breastfeeding status, and there is posyandu contextual influence in the factors that influence in giving Exclusive breastfeeding. The relationship of variables and the influence of contextual at posyandu level can be seen in Table 2 . 
Journal of Maternal and Child Health (2018), 3(3): 176-183

https://doi.org/10.26911/thejmch.2018.03.03.02

Table 2. The results of multilevel logistic regression on exclusive breastfeeding

\begin{tabular}{|c|c|c|c|c|}
\hline \multirow{2}{*}{ Independent Variable } & \multirow{2}{*}{ b } & \multicolumn{2}{|c|}{ 95\% CI } & \multirow{2}{*}{$\mathbf{p}$} \\
\hline & & Lower Limit & Upper Limit & \\
\hline Subjective norm & $4 \cdot 31$ & 1.63 & 6.99 & $<0.002$ \\
\hline Leisure time for breastfeeding & 3.97 & 1.12 & 6.81 & $<0.006$ \\
\hline Attitude & 3.01 & 0.57 & 5.45 & $<0.016$ \\
\hline Husband support & 2.40 & 0.29 & 4.51 & $<0.026$ \\
\hline Family support & 2.71 & 0.46 & 4.97 & $<0.018$ \\
\hline Health personnel support & 4.13 & 1.28 & 6.98 & $<0.005$ \\
\hline $\begin{array}{l}\mathrm{ICC}=69.47 \% \\
\text { Likelihood Ratio Test } \mathrm{p}=-37.67\end{array}$ & & & & \\
\hline
\end{tabular}

Exclusive breastfeeding was positively affected by positive subjective norm $(\mathrm{b}=$ $4.31 ; 95 \% \mathrm{CI}=1.63$ to $6.99 ; \mathrm{p}=0.002)$, leisure time $(\mathrm{b}=3.97 ; 95 \% \mathrm{CI}=1.12$ to 6.81 ; $\mathrm{p}=0.006)$, positive attitude $(\mathrm{b}=3.01 ; 95 \%$ $\mathrm{CI}=0.57$ to $5.45 ; \mathrm{p}=0.016$ ), strong husband support $(b=2.39 ; 95 \% \mathrm{CI}=0.29$ to $4.51 ; \mathrm{p}=$ 0.026), strong family support $(b=2.71 ; 95 \%$ $\mathrm{CI}=0.46$ to $4.97 ; \mathrm{p}=0.018$ ), and health personnel support $(b=4.13 ; 95 \% \mathrm{CI}=1.28$ to $6.99 ; \mathrm{p}=0.005$ ).

\section{DISCUSSION}

\section{The effect of subjective norm on} exclusive breastfeeding

The result of this study showed that there was an effect of subjective norm on exclusive breastfeeding. Mothers who had strong subjective norm increased exclusive breastfeeding compared to mothers who have weak subjective norms.

This study was in accordance with a study by Teklehaymanot (2013) and Sinta, (2018), which stated that there was a strong correlation between subjective norm and exclusive breastfeeding behavior.

This study is also consistent with Ostovar (2017) that maternal behavior in exclusive breastfeeding was influenced by subjective norms ( Jamehei et al., 2017).

Subjective norm was the perception of individual or group to conduct a behavior that was affected by social pressure around them, if the individual believed the norms in the group, then the individual would obey or follow the norms (Sulaeman, 2016). The subjective norm came from people who were considered important and worthy to be imitated, then the role of family, officers, and closest people would formed the subjective norm.

\section{The effect of leisure time for breastfeeding on exclusive breast- feeding.}

The result of this study showed that there was an effect of leisure time for breastfeeding on exclusive breastfeeding. Mother who had free time increased the likelihood of exclusive breastfeeding. This study is consistent with a study by Isroni (2017), which stated that there was a positive association between leisure time for breastfeeding on exclusive breastfeeding (Isroni, 2013). Kaushal et al., (2017) reported that exclusive breastfeeding was determined by social economy, maternal age, parental education, leisure time, paternal employment, and EIFB.

One of the problems in breastfeeding was in working mother, 8 hours working time which caused the mother to have less free time to breastfeed, and also the government leave issue which did not support full exclusive breastfeeding for 6 months and also because of poor maternal knowledge in lactation management and also supported 
by the unavailability of a lactation corner in the workplace (Abdullah, 2012). The availability of a lactation corner and government policy in giving maternity day off to working mothers was a positive thing that greatly contributed to success in exclusive breastfeeding.

\section{The effect of attitude on exclusive breastfeeding.}

The result of this study showed that exclusive breastfeeding was affected by attitude. Maternal positive attitude increased the likelihood of exclusive breastfeeding. This study is consistent with a study by Ostovar (2017), which stated that maternal behavior to exclusive breastfeeding was influenced by factors such as subjective behavior and perceived control behavior.

Asemahagn (2016) reported that attitute was an evaluative statement of the object either in the form of an individual or events, whose response was still closed to the stimulus or object, which was oriented toward favorable or unfavorable feelings on an object, and was also a predisposition to respond positively or negatively.

\section{The effect of husband support on exclusive breastfeeding}

The result of this study showed that exclusive breastfeeding was affected by husband support. Mothers who received strong husband support increased the likelihood of exclusive breastfeeding. This study is consistent with a study by Abdullah (2012), which stated that husband played an important role in facing difficult times that weaken the mothers in the process of breastfeeding, the results of this study stated that $57 \%$ of mothers got support from their husbands in exclusive breastfeeding. Mothers with husbands who support exclusive breastfeeding have the opportunity to exclusively breastfeed by two times than mothers who have less supportive husbands in exclusive breastfeeding.

Husband was the closest person to the mother and was expected to give huge attention to his wife, husband has a very important role in the process of breastfeeding which was related to wife's emotional conditions and feelings, because it was associated with increased levels of maternal oxytocin which related to breast milk production (Abdullah, 2012). The success of exclusive breastfeeding in addition to depend on mother and baby, it was also depend on the support of the husband.

\section{The effect of family support on exclusive breastfeeding}

The result of this study showed that exclusive breastfeeding was affected by family support. Strong family support increased the likelihood of exclusive breastfeeding. This study is consistent with a study by Abdullah (2012), which stated that family environment factors including family structure, history, and parenting and child relationship patterns. Family with poor behavior decreased exclusive breastfeeding. $64 \%$ of mothers who exclusively breastfed received strong family support (Tampah et al., 2013).

Family have an important role in providing a model for forming the values, beliefs, and characters of the child, especially in breastfeeding behavior (Yalçin, et al., 2016).The role of parents in the formation of behavior was needed in adolescence which was known as the difficult time in growing up. This was because adolescence was a transition period between children into adulthood, this transitional period often confronted the teenagers in a confusing situation, and usually this confusing situation was overcomed by uncontrolled behaviors, one of them was breastfeeding behavior (Mustika, 2017). The success of exclusive breastfeeding depends not only 
for maternal factor but also the support of family.

\section{The effect of health personnel support on exclusive breastfeeding}

The result of this study stated that exclusive breastfeeding was affected by health personnel support. This study is consistent with a study by Windari (2017). Mothers who have lack of support from health personnel have 10.5 times greater likelyhood to not provide exclusive breastfeeding than mothers who received support from health personnel.

Mamonto (2015) stated that there was an effect of health personnel support on exclusive breastfeeding. Mothers with health personnel support were 4.13 times greater to give exclusive breastfeeding.

Health personnel was a person who provided services related to public health which in this case may be medical and paramedical or paramedical assistant, one of the aspects that support the success of breastfeeding was the role of health personnel, otherwise the officers who ignore and underestimate the mothers who have problems in breastfeeding would have a negative effect on mothers who breastfeed (Abdullah, 2012). Midwives have a very special role in providing support to achieve success in breastfeeding, convincing and helping the mothers was the beginning of midwives' role in providing support to breastfeeding mothers.

Health personnel was associated with exclusive breastfeeding. Health personnel may negatively influence passive method, which was by being indifferent or neutral in mothers with breastfeeding problems (Abdullah, 2012).

Based on the descriptions above, it can be concluded that the results of multilevel analysis in this study showed that there was $69.47 \%$ exclusive breast- feeding was determined by mother visit to community health center.

\section{CONFLICT OF INTEREST}

None declared.

\section{REFERENCES}

$\overline{\text { Abdullah GI (2012). Determinan pemberian }}$ asi eksklusif pada ibu bekerja di Kementerian Kesehatan RI tahun 2012.

Agho KE, Dibley MJ, Odiase JI, Ogbonmwan SM (2011). Determinants of exclusive breastfeeding in Nigeria. BMC Pregnancy and Childbirth, 11(1), 2. https://doi.org/10.1186/1471-239311-2.

Asemahagn MA (2016). Determinants of exclusive breastfeeding practices among mothers in Azezo District, Northwest Ethiopia. International Breastfeeding Journal, 11(1), 22. https://doi.org/10.1186/s13006-016oo81-x.

Astuti I (2013). Determinan pemberian ASI eksklusif pada ibu menyusui. Health Quality, 4, 1-76.

Didik B, Hardhana B, Yudianto M, Soenardi $\mathrm{T}$ (2016). Data and information Indonesia health profile 2016. Yoeyoen Aryantin Indrayani S.Ds; B. B. Sigit; Sinin, 168. Retrieved from http://www.depkes.go.id/resources/downloa $\mathrm{d} /$ pusdatin/lain-lain/Datadan Informasi Kesehatan Profil Kesehatan Indonesia 2016-smaller size - web.pdf

Dinas Kesehatan Kota Surabaya. (2016). Profil kesehatan Kota Surabaya, 194. Diakses November 2017.

Irianto K (2014). Balance nutrition in reproductive health. Bandung: Alfabeta.

Isroni A (2013). Determinan pemberian asi ekslusif pada ibu menyusui. Jurnal Health Quality, 4, 1-76. 
Ostovar J, Javadyade H (2017). Predictors of exclusive breastfeeding among nulliparous Iranian mothers: application of the theory of planned behaviour. International Journal of Pediatrics.

Kaushal A, Singh M, Sharma P, Chander V, Kumar RS (2017). Determinants of exclusive breastfeeding among lactating women in sub-Himalayan region, 70-74. https://doi.org/10.4103/1119o388.198128.

Kementrian Kesehatan RI (2012). Ayo ke Posyandu seiap bulan, Jakarta Bhakti Husada Diakses November 2017.

Mamonto T (2015). Faktor-faktor yang berhubungan dengan ASI eksklusif pada bayi di wilayah kerja puskesmas Kotobangon kecamatan Kotamobagu Timur kota Kotamobagu. Universitas Sam Ratulangi.

Murti B (2013). Desain dan ukuran sampel untuk penelitian kuantitatif dan kualitatif di bidang kesehatan. Yogyakarta: Gadjah Mada University Press.

Mustika I (2017). Determinan pemberian asi eksklusif pada ibu menyusui tinjauan sistematis penelitian tahun 2011 - 2016 exclusive breastfeeding determinants in breastfeeding mother a systematic research review 2011 2016, 1(4), 15-21.

Ramandey S (2017). Kebidanan teori dan asuhan Vol. 2. Jakarta: EGC.

Riyanto A (2011). Aplikasi metodologi penelitian kesehatan. Yogyakarta: Nuha Medika.

Riyanto A (2013). Kapita selekta kuesioner pengetahuan dan sikap dalam pene- litian kesehatan. Jakarta: Salemba Medika.

Sinta P (2018). Multilevel analysis on the biopsychosocial and economic determinants of exclusive breastfeeding.

Sulaeman ES (2016). Pembelajaran model dan teori perilaku kesehatan konsep dan aplikasi. Surakarta: UNS PRESS.

Tampah-Naah AM, Kumi-Kyereme A (2013). Determinants of exclusive breastfeeding among mothers in Ghana: a cross-sectional study. International Breastfeeding Journal, 8(1), 13. https://doi.org/10.1186/1746-4358-8-13

Teklehaymanot A, Hailu A, Wossen B (2013). Intention of exclusive breastfeeding among pregnant women using theory of planned behaviour in Medebay Zana District, Tigray Region, North Etiopia. Public Health Research, 3(6).

WHO (2016). Breastfeeding. WHO. Retrieved from http://www.who.int/maternal_child_adolescent/topics/newbor $\mathrm{n} /$ nutrition/breastfeeding/en/Diakses November 2017

Windari E, Dewi A, Siswanto (2017). Pengaruh dukungan tenaga kesehatan terhadap pemberian ASI eksklusif di wilayah kerja Puskesmas Sisir Kota Baru. Journal of Issue in Midwifery.

Yalçin SS, Berde AS, Yalçin S (2016). Determinants of exclusive breast feeding in sub-Saharan Africa: A multilevel approach. Paediatric and Perinatal Epidemiology, 30(5): $\quad 439-449$. https://doi.org/10.1111/ppe.12305 